\title{
Anoxybacillus pushchinensis gen. nov., sp. nov., a novel anaerobic, alkaliphilic, moderately thermophilic bacterium from manure, and description of Anoxybacillus flavithermus comb. nov.
}

\author{
Elena Pikuta, ${ }^{2 \dagger}$ Anatolyi Lysenko, ${ }^{1}$ Natalya Chuvilskaya, ${ }^{2}$ \\ Ulrike Mendrock, ${ }^{3}$ Hans Hippe, ${ }^{3}$ Natalya Suzina, ${ }^{2}$ Dmitriy Nikitin, ${ }^{2}$ \\ Georgiy Osipov ${ }^{4}$ and Kestas Laurinavichius ${ }^{2}$
}

Author for correspondence: Elena Pikuta. Tel: +1 256544 7619. Fax: +1 2565445956 e-mail: elenapikuta@hotmail.com

1 Institute of Microbiology, Russian Academy of Sciences, Pr. 60-letya Oktyabrya, Moscow 117811, Russia

2 Institute of Biochemistry and Physiology of Microorganisms, Russian Academy of Science, pr. Nauki 5, Pushchino 142292, Russia

3 DSMZ, Mascheroder Weg 1b, D-38124 Braunschweig, Germany

4 Academician Yu. Isakov Scientific Group, Russian Academy of Medical Sciences, Moscow, Russia

\begin{abstract}
A new strictly anaerobic, alkaliphilic, moderately thermophilic, fermentative, spore-forming bacterium, strain $\mathrm{K}^{\mathrm{T}}$, was isolated from manure samples ( $\mathrm{pH}$ 6.8). Cells were Gram-positive, straight, non-motile rods that grew at temperatures of 37-66 ${ }^{\circ} \mathrm{C}$ (optimum at $62^{\circ} \mathrm{C}$ ) and in a $\mathrm{pH}$ range of 8.0-10.5 (optimum at 9.5-9.7). The bacterium fermented D-glucose, sucrose, D-fructose, D-trehalose and starch as carbon and energy sources. It required vitamins and its growth is stimulated by yeast extract. The major metabolic products were $\mathrm{H}_{2}$ and acetate. Cells were catalase-negative and could reduce nitrate to nitrite. The $\mathrm{G}+\mathrm{C}$ content of the DNA was $\mathbf{4 2 \cdot 2} \mathrm{mol} \%$. Based on the phenotypic properties and 165 rDNA sequencing and DNA-DNA hybridization data, strain K1 $^{\top}$ ( = DSM $12423^{\top}={\text { ATCC } 700785^{\top}}^{\top}=$ VKM B-2193 $^{\top}$ ) was assigned to the new genus Anoxybacillus gen. nov., as a representative of a new species, Anoxybacillus pushchinensis sp. nov. 'Bacillus flavothermus' strain d.y., which was found to be closely related to strain $\mathrm{K1}^{\mathrm{T}}$, is described as Anoxybacillus flavithermus comb. nov. (type strain $=$ d.y. ${ }^{\top}=$ DSM 2641 ${ }^{\top}$ ).
\end{abstract}

Keywords: anaerobic alkaliphilic thermophilic bacterium, Anoxybacillus pushchinensis gen. nov., sp. nov., Anoxybacillus flavithermus comb. nov.

\section{INTRODUCTION}

Alkaliphilic bacteria can be subdivided into two groups which include obligately alkaliphilic species that are unable to grow at neutral $\mathrm{pH}$, and alkalitolerant bacteria that are able to grow at high $\mathrm{pH}$ values but have their growth optimum at or near a neutral pH (Grant \& Tindall, 1986). Alkalitolerant bacteria of the species Streptococcus faecalis were first described in 1928 (Downie \& Cruickshank, 1928). Obligately alkaliphilic bacteria of the genera Bacillus and Clostridium have been isolated from soils with neutral pH (Horikoshi \& Akiba, 1982). Later, meso-

† Present address: UAH Chemistry Department, Astrobiology Group, MSB 203C, Huntsville, AL 35899, USA.

The GenBank accession number for the 16S rDNA sequence of Anoxybacillus pushchinensis strain $\mathrm{K} 1^{\top}$ is $\mathrm{AJ} 010478$. philic alkaliphilic bacteria were found in soda lakes (Grant \& Tindall, 1986; Krulwich \& Guffanti, 1989; Zavarzin, 1993). More recently, thermophilic, alkaliphilic, anaerobic bacteria have been isolated from sewage (Li et al., 1993, 1994) and thermal springs (Engle et al., 1995). These investigations expanded our knowledge about the biodiversity and ecology of alkaliphilic bacteria. For some of these bacteria, however, the optimal growth conditions differ remarkably from the conditions in their habitats and the role of such micro-organisms in these ecosystems is not well understood yet. In this work, Anoxybacillus pushchinensis gen. nov., sp. nov. is described, a new species of the strictly anaerobic, moderately thermophilic, obligately alkaliphilic bacilli isolated from manure with neutral $\mathrm{pH}$. Since the new species was found to be closely related genetically to 'Bacillus flavothermus' (Heinen et al., 1982), this hitherto 
invalidly named species is described as Anoxybacillus flavithermus comb. nov. (name corrected).

\section{METHODS}

Strains, media and culture conditions. Strain $\mathrm{K} 1^{\mathrm{T}}$ was isolated from enrichment cultures that had been inoculated with mixed manure samples and grown under anaerobic conditions in Hungate tubes at $60^{\circ} \mathrm{C}$ for $4 \mathrm{~d}$. Samples of equine and porcine manure $(1: 1, \mathrm{w} / \mathrm{w})$ with a $\mathrm{pH}$ of $6 \cdot 0-7 \cdot 0$ were collected from farms in the Moscow region and stored at $4{ }^{\circ} \mathrm{C}$ before inoculation.

For the enrichment, isolation and cultivation of strain $\mathrm{K} 1^{\mathrm{T}}$, a previously described anaerobic basal medium (Zhilina et $a l ., 1997)$ was used with certain modifications. The medium contained $\left(\mathrm{g} \mathrm{l}^{-1}\right)$ : $\mathrm{KH}_{2} \mathrm{PO}_{4}, 0 \cdot 2 ; \mathrm{MgCl}_{2} .6 \mathrm{H}_{2} \mathrm{O}, 0 \cdot 1 ; \mathrm{KCl}$, $0 \cdot 2 ; \mathrm{NH}_{4} \mathrm{Cl}, 1 \cdot 0 ; \mathrm{Na}_{2} \mathrm{CO}_{3}, 2 \cdot 76 ; \mathrm{NaHCO}_{3}, 10 \cdot 0 ; \mathrm{NaCl}, 5 \cdot 0$; $\mathrm{Na}_{2} \mathrm{~S} .9 \mathrm{H}_{2} \mathrm{O}, 0.5$. The $\mathrm{pH}$ of the medium after autoclaving was 9.5-9.7. After sterilization at $120^{\circ} \mathrm{C}$ for $30 \mathrm{~min}$, yeast extract $\left(0 \cdot 01 \mathrm{~g} \mathrm{l}^{-1}\right)$ and glucose as carbon source $\left(5 \cdot 0 \mathrm{~g} \mathrm{l}^{-1}\right)$ were added. Medium (1 1) was supplemented with $10 \mathrm{ml}$ of a stock vitamin solution (Wolin et al., 1963) and $1 \mathrm{ml}$ of a trace element solution containing $(\mathrm{mg}$ per $200 \mathrm{ml}$ water): $\mathrm{MnCl}_{2} .4 \mathrm{H}_{2} \mathrm{O}, 720 ; \mathrm{Fe}\left(\mathrm{NH}_{4}\right)\left(\mathrm{SO}_{4}\right)_{2} .12 \mathrm{H}_{2} \mathrm{O}, 400$; $\mathrm{FeSO}_{4} \cdot 7 \mathrm{H}_{2} \mathrm{O}, 200 ; \mathrm{CoCl}_{2} \cdot 6 \mathrm{H}_{2} \mathrm{O}, 200 ; \mathrm{ZnSO}_{4} \cdot 7 \mathrm{H}_{2} \mathrm{O}, 200$; $\mathrm{Na}_{2} \mathrm{MoO}_{4} \cdot 2 \mathrm{H}_{2} \mathrm{O}, 20 ; \mathrm{NiCl}_{2}, 100 ; \mathrm{CuSO}_{4} .5 \mathrm{H}_{2} \mathrm{O}, 20$; $\mathrm{AlK}\left(\mathrm{SO}_{4}\right)_{2} .12 \mathrm{H}_{2} \mathrm{O}, 20 ; \mathrm{H}_{3} \mathrm{BO}_{3}, 20$; and $5 \mathrm{ml}$ concentrated $\mathrm{HCl}$.

Unless otherwise indicated, enrichment and pure cultures were grown at $55-62{ }^{\circ} \mathrm{C}$ in $15 \mathrm{ml}$ Hungate tubes containing $10 \mathrm{ml}$ medium and filled with $\mathrm{N}_{2}$. All sampling and dispensing procedures were performed with sterile syringes and needles. Prior to roll-tube cultivation on 3\% Difco agar $(\mathrm{w} / \mathrm{v})$, aliquots of separately sterilized carbonate solutions were added, in addition to yeast extract and glucose, to Hungate tubes with $4 \mathrm{ml}$ sterile basal medium.

In the series of experiments designed to elucidate the optimal growth conditions, the $\mathrm{pH}$ of the medium was adjusted to required values with sterile stock solutions of $\mathrm{HCl}$ or $\mathrm{NaOH}$ at $55^{\circ} \mathrm{C}$ under an $\mathrm{N}_{2}$ flow. $\mathrm{pH}$ measurements were done using a model $121 \mathrm{pH}$ meter (Russia) calibrated at $55^{\circ} \mathrm{C}$. Cells were grown at $55^{\circ} \mathrm{C}$. To determine the range of growth temperatures, the isolate was cultivated in the basal medium ( $\mathrm{pH} 9 \cdot 7)$.

The effect of $\mathrm{NaCl}$ on the bacterial growth was studied in basal medium containing $0 \cdot 0,0 \cdot 5,1 \cdot 0,2 \cdot 0,3 \cdot 0,5 \cdot 0$ or $7 \cdot 0 \%$ $(\mathrm{w} / \mathrm{v}) \mathrm{NaCl}$. The medium was modified to exclude other sodium sources by replacing $\mathrm{Na}_{2} \mathrm{CO}_{3}$ and $\mathrm{NaHCO}_{3}$ with $5 \mathrm{~g} \mathrm{l}^{-1} \mathrm{~K}_{2} \mathrm{CO}_{3}$, and $\mathrm{Na}_{2} \mathrm{~S}$ with $\mathrm{K}_{2} \mathrm{~S}$. The $\mathrm{NH}_{4} \mathrm{Cl}$-dependence of the strain was estimated in medium containing $0,0.5,1 \cdot 0$ or $3.0 \%(\mathrm{w} / \mathrm{v}) \mathrm{NH}_{4} \mathrm{Cl}$.

Carbon sources other than glucose were added to the medium in the form of autoclaved or filter-sterilized solutions to a final concentration of $5 \mathrm{~g} \mathrm{l}^{-1}$. Sterile stock solutions of electron acceptors were added to the medium with glucose $\left(5 \mathrm{~g}^{-1}\right)$ to the following final concentrations: $\mathrm{Na}_{2} \mathrm{SO}_{4}, 20 \mathrm{mM} ; \mathrm{Na}_{2} \mathrm{SO}_{3}, 5 \mathrm{mM}$; $\mathrm{Na}_{2} \mathrm{~S}_{2} \mathrm{O}_{3} .5 \mathrm{H}_{2} \mathrm{O}, 10 \mathrm{mM}$; $\mathrm{NaNO}_{3}, 10 \mathrm{mM}$; benzenesulfonate, $5 \mathrm{mM}$; fumarate, $10 \mathrm{mM} ; \mathrm{S}^{0}, 2 \mathrm{~g}^{-1}$

Light and electron microscopy. The morphology of the isolate was examined under an MBI-3 LOMO (Russia) microscope with a phase-contrast device. For electron microscopy studies, harvested cells were pre-fixed with $1.5 \%$ $(\mathrm{v} / \mathrm{v})$ glutaraldehyde in $0.05 \mathrm{M}$ cacodylate buffer $(\mathrm{pH} 7 \cdot 2)$ for $1 \mathrm{~h}$ at $5{ }^{\circ} \mathrm{C}$, washed three times with the buffer, and fixed with $1 \% \mathrm{OsO}_{4}$ in $0.05 \mathrm{M}$ cacodylate buffer $(\mathrm{pH} 7 \cdot 2)$ for $4 \mathrm{~h}$ at $20{ }^{\circ} \mathrm{C}$. After dehydration in a series of ethanol solutions, cells were embedded in Epon 812 and sectioned on a microtome, LKB 2128 Ultratome. Ultrathin sections were placed onto copper grids and negatively stained with $3 \%$ uranyl acetate in ethanol with lead citrate (Reynolds, 1963). Thin sections were examined under a JEOL JEM-100B electron microscope.

Analytical, physiological and biochemical methods. The bacterial cell number was determined by direct counting under a light microscope. The optical density (OD) of cell suspensions was measured in $1 \mathrm{~cm}$ cuvettes at $600 \mathrm{~nm}$ using a model 11 Specol spectrophotometer. Catalase activity was assessed as described elsewhere (Gerhardt et al., 1984) with $3 \% \mathrm{H}_{2} \mathrm{O}_{2}$ added to the culture liquid. Volatile products of glucose fermentation were analysed with the use of a Pye Unicam 304 GC with FID and a $0.9 \mathrm{~m} \times 3.3 \mathrm{~mm}$ Chromosorb 101 column kept at $160{ }^{\circ} \mathrm{C} ; \mathrm{CO}_{2}$ served as the carrier gas. $\mathrm{NO}_{2}$ was determined by the colorimetric method (Tiedje, 1982).

Cellular fatty acids. Fatty acids and other lipid components were extracted from cell biomass by acid methanolysis. Wet biomass $(30 \mathrm{mg})$ was dried in a stream of nitrogen and $400 \mathrm{ml}$ of a $1 \mathrm{M}$ solution anhydrous $\mathrm{HCl}$ in methanol was added. The mixture was heated at $80^{\circ} \mathrm{C}$ for $3 \mathrm{~h}$. The methyl esters of fatty acids and dimethylacetates (aldehyde derivatives) were obtained as a result, and were extracted twice with $200 \mathrm{ml}$ hexane. The extract was evaporated to dryness

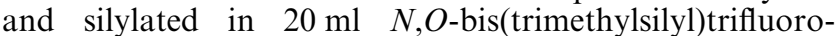
acetamide for $15 \mathrm{~min}$ at $80^{\circ} \mathrm{C}$. A $1 \mathrm{ml}$ portion of the reaction mixture was analysed with a model QP-2000 GC-MS system (Shimadzu) equipped with a fused silica capillary column $(25 \mathrm{~m} \times 0.25 \mathrm{~mm})$ containing an Ultra-1 non-polar methylsilicone phase. The temperature profile included a $2 \mathrm{~min}$ isotherm at $120^{\circ} \mathrm{C}$ and subsequent temperature programming at a rate of $5^{\circ} \mathrm{C} \mathrm{min}-1$ to $280{ }^{\circ} \mathrm{C}$. Data processing was carried out with standard programs of the GC-MS system.

Resistance to antibiotics. Resistance to antibiotics was evaluated by growing the bacterium in basal medium supplemented with filter-sterilized bacitracin, chloramphenicol $\left(100 \mu \mathrm{g} \mathrm{ml}^{-1}\right)$, penicillin, ampicillin, streptomycin or vancomycin (all at $250 \mu \mathrm{g} \mathrm{ml}^{-1}$ ). After the inoculation of antibiotic-containing media with exponentially growing cells, the cultures were incubated at $37^{\circ} \mathrm{C}$ for $12 \mathrm{~h}$ and then at $55^{\circ} \mathrm{C}$ for $14 \mathrm{~d}$.

G $+\mathbf{C}$ content determination and DNA hybridization. Cells were disrupted with a French pressure cell and DNA was isolated by chromatography on hydroxyapatite by the procedure of Cashion et al. (1977). The $\mathrm{G}+\mathrm{C}$ content of the DNA was determined by HPLC as described by Tamaoka \& Komagata (1984) and Mesbah et al. (1989). Non-methylated lambda phage DNA (Sigma) with a $\mathrm{G}+\mathrm{C}$ content of $49.858 \mathrm{~mol} \%$ served as a standard. DNA-DNA hybridization was performed as described by De Ley et al. (1970) with modifications described by $\mathrm{Huß}$ et al. (1983) and Escara \& Hutton (1980), using a Gilford System 2600 spectrophotometer equipped with a Gilford model 2527-R thermoprogrammer and plotter. The renaturation rates were computed using the TRANSFER.BAS program (Jahnke, 1992).

Phylogenetic analysis. Chromosomal DNA of strain $\mathrm{K} 1^{\mathrm{T}}$ was isolated and purified as described elsewhere (Marmur, 1961) and 16S rDNA was then amplified by Thermus aquaticus thermostable DNA polymerase (USB) via PCR in a mixture containing $1 \times$ TaqPol buffer (USB), $0.2 \mathrm{mg}$ chromosomal DNA, 20 pM oligonucleotide primers $\mathrm{pA}$ and $\mathrm{pH}^{\prime}$ (Edwards et al., 1989), $2.5 \mathrm{mM}$ dNTP, $2.5 \mathrm{mM} \mathrm{MgCl}_{2}$ 
and $2 \mathrm{U}$ Taqr. After denaturation at $94^{\circ} \mathrm{C}$ for $5 \mathrm{~min}$, the reaction mixture was subjected to 30 thermal cycles $\left(52^{\circ} \mathrm{C}\right.$, $\left.1 \mathrm{~min} ; 72{ }^{\circ} \mathrm{C}, 1.5 \mathrm{~min} ; 94{ }^{\circ} \mathrm{C}, 1 \mathrm{~min}\right)$. PCR products were sequenced using the FemtoMol kit (Promega). 16S rDNA was sequenced in both strands by Sanger's method using next primers: $\mathrm{pA}, \mathrm{pC}, \mathrm{pE}, \mathrm{pD}^{\prime}, \mathrm{pF}^{\prime}$ and $\mathrm{pH}^{\prime}$ (Edwards et al., 1989). All procedures were done as directed in the manufacturer's protocol. The $16 \mathrm{~S}$ rDNA sequence of strain $\mathrm{K} 1^{\mathrm{T}}$ was aligned against those of closely related strains using the CLUSTAL program (version 1.60). Pairwise evolutionary distances were computed by the correction of Jukes and Cantor (Felsenstein, 1989) using the DNADIST program from the PHYLIP software package (version 3.5). A 16S rDNA sequence of $1340 \mathrm{nt}$ was registered in GenBank under the accession number AJ010478.

\section{RESULTS}

\section{Enrichment and pure cultures}

A population of anaerobic, alkaliphilic, moderately thermophilic bacteria developed in glucose-containing medium $(\mathrm{pH} \mathrm{10.0)}$ that had been inoculated with mixed manure samples, which had a neutral $\mathrm{pH}(6 \cdot 8)$, and incubated under anaerobic conditions at $60{ }^{\circ} \mathrm{C}$ for $4 \mathrm{~d}$.

From this enrichment culture (OD of $0 \cdot 4$ ), serial dilutions were prepared and used for inoculation of the same medium supplemented with penicillin $\left(500 \mu \mathrm{g} \mathrm{ml}^{-1}\right)$ and streptomycin $\left(500 \mu \mathrm{g} \mathrm{ml}^{-1}\right)$. The highest dilution exhibiting growth of anaerobic alkaliphilic bacteria was pure as judged from the absence of growth at $\mathrm{pH} 7 \cdot 0$ in glucose-peptone medium with large amounts of yeast extract. This culture was anaerobically grown in roll-tubes with agar medium, and one of the colonies formed (referred to as strain $\mathrm{K} 1^{\mathrm{T}}$ ) was selected for further studies.

\section{Morphology}

Strain $\mathrm{K} 1^{\mathrm{T}}$ was a Gram-positive, non-motile, straight, spore-forming rod with rounded ends, measuring $0.4-0.5 \times 2.5-3.0 \mu \mathrm{m}$. It formed terminal and subterminal spherical endospores. Interestingly, spores were found only after storage at $-40{ }^{\circ} \mathrm{C}$ and $12 \mathrm{~h}$ post-incubation at $22^{\circ} \mathrm{C}$. Cells occurred singly, in pairs or in short or, sometimes, long chains (Fig. 1a). Cells reproduced by binary fission; Y-shaped cells sometimes occurred (Fig. 1b, f). The cell wall, visible as a narrow electron-dense layer, was of the Grampositive type. The outer part of the cell envelope consisted of two structurally ordered S-layers covered with a thick peptidoglycan layer (Fig. 1d).

\section{Cultural, physiological and biochemical properties}

After $2-3 \mathrm{~d}$ cultivation on agar medium at $55^{\circ} \mathrm{C}$, the colonies of strain $\mathrm{K} 1^{\mathrm{T}}$ were white, matt, dentate, rough and from 0.5 to $2.0 \mathrm{~mm}$ in diameter. Surface colonies were round and granular, with a dense centre. Subsurface colonies were round, white, with a dense yellowish centre and uneven edges.

Strain $\mathrm{K} 1^{\mathrm{T}}$ grew strictly anaerobically $\left(\mathrm{E}_{\mathrm{h}}<-100\right.$
$\mathrm{mV}$ ) in medium with glucose as the carbon and energy source; growth was stimulated by vitamins and yeast extract. The bacterium was catalase-negative and able to reduce nitrate to nitrite. It did not hydrolyse gelatin or casein.

Growth was observed in a $\mathrm{pH}$ range of $8 \cdot 0-10 \cdot 5$ (Fig. 2a), with an optimum at 9.5-9.7. At $\mathrm{pH} 9 \cdot 7$, cells began to multiply after a very short lag phase. Strain $\mathrm{K} 1^{\mathrm{T}}$ could not grow in media with $\mathrm{pH}$ values of $7 \cdot 5$ or 11.0 . The bacterium obligately required carbonate for growth; it could not grow in carbonate-free glycine- or serine-buffered media ( $\mathrm{pH} 9 \cdot 5)$ with glucose $\left(5 \mathrm{~g}^{-1}\right)$. Strain $\mathrm{K} 1^{\mathrm{T}}$ grew well, however, in carbonate-containing medium with glycine and serine $\left(5 \mathrm{~g}^{-1}\right)$; therefore, these amino acids had no inhibitory effect. Hence, strain $\mathrm{K}^{\mathrm{T}}$ is an alkaliphile that is obligately dependent on carbonate. The concentrations of $\mathrm{NaCl}$ optimal for growth ranged from 0.5 to $1 \%(\mathrm{w} / \mathrm{v})$. The strain was tolerant to $3 \%(\mathrm{w} / \mathrm{v}) \mathrm{NaCl}$ but could not grow at $5 \%(\mathrm{w} / \mathrm{v}) \mathrm{NaCl}$. Strain $\mathrm{K} 1^{\mathrm{T}}$ was not obligately $\mathrm{Na}^{+}$-dependent: it grew in medium with $\mathrm{K}^{+}$salts substituted in equimolar amounts for $\mathrm{Na}^{+}$salts (three successive inoculations). Since strain $\mathrm{K} 1^{\mathrm{T}}$ was isolated from manure, it was important to study its requirement for $\mathrm{NH}_{4}^{+}$. The strain showed good growth at $\mathrm{NH}_{4} \mathrm{Cl}$ concentrations of $0 \cdot 1-0.5 \%(\mathrm{w} / \mathrm{v})$, with an optimum at $0.1 \%(\mathrm{w} / \mathrm{v}) \mathrm{NH}_{4} \mathrm{Cl}$, but not at $1 \%(\mathrm{w} / \mathrm{v}) \mathrm{NH}_{4} \mathrm{Cl}$. The temperature range for growth was $37-66{ }^{\circ} \mathrm{C}$, with an optimum at $62^{\circ} \mathrm{C}$ (Fig. 2b). Therefore, strain $\mathrm{K} 1^{\mathrm{T}}$ is a moderate thermophile.

In addition to D-glucose, strain $\mathrm{K} 1^{\mathrm{T}}$ was capable of fermenting sucrose, D-fructose, D-trehalose and starch $\left(5 \mathrm{~g}^{-1}\right)$. The major metabolic products were $\mathrm{H}_{2}$ and acetate. No growth was observed with formate, acetate, propionate, pyruvate, lactate, butyrate, methanol, ethanol, glycerol, yeast extract, peptone, methylamine, casein, L-cysteine, L-valine, sorbitol, dulcitol, mannitol, inositol, L-sorbose, D-melezitose, L-rhamnose, DL-arabinose, D-galactose, D-melibiose, D-raffinose, Dribose, D-lactose or DL-xylose.

Strain $\mathrm{K} 1^{\mathrm{T}}$ was able to reduce $\mathrm{NaNO}_{3}$ to $\mathrm{NaNO}_{2}$, but it could not use $\mathrm{Na}_{2} \mathrm{SO}_{4}, \mathrm{Na}_{2} \mathrm{SO}_{3}, \mathrm{Na}_{2} \mathrm{~S}_{2} \mathrm{O}_{3} .5 \mathrm{H}_{2} \mathrm{O}, \mathrm{S}^{0}$ or benzenesulfonate as electron acceptors; no formation of $\mathrm{H}_{2} \mathrm{~S}$ was observed during growth in media containing sulfur compounds.

The bacterium studied was sensitive to bacitracin (at $100 \mu \mathrm{g}^{-1}$ ), but resistant to penicillin, vancomycin, ampicillin and streptomycin (all at $250 \mu \mathrm{g} \mathrm{ml}^{-1}$ ), and chloramphenicol $\left(100 \mu \mathrm{g} \mathrm{ml}^{-1}\right)$.

\section{Cellular fatty acids}

The cellular fatty acid profile of strain $\mathrm{K} 1^{\mathrm{T}}$ (Table 1 ) differed (at a correlation level of $k>0 \cdot 5$ ) from that of 435 strains of various taxonomic groups, including 80 species of Bacillus, available in the database (obtained from one of the authors, G. Osipov, private collection). This implies that the studied bacterium cannot be consigned to any of the known species of the genus Bacillus. 


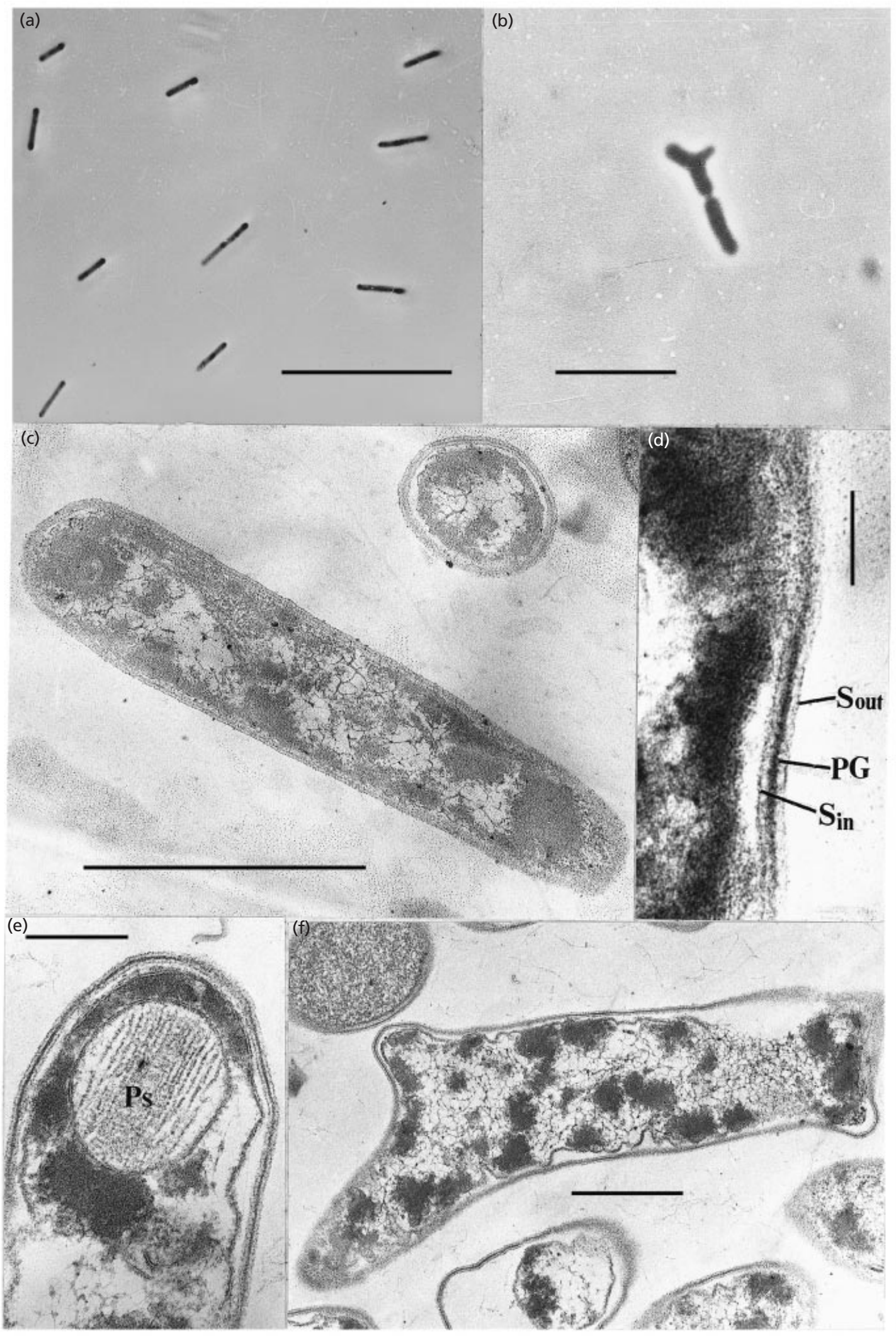

Fig. 1. Electron micrographs of cells of strain $K 1^{\top}$. (a) Light micrograph (bar, $16 \cdot 0 \mu \mathrm{m}$ ); (b) light micrograph of a branching form (bar, $3 \mu \mathrm{m})$; (c) ultrathin section (bar, $1.0 \mu \mathrm{m})$; (d) ultrathin section of the Gram-positive cell wall $\left(\mathrm{S}_{\text {out, }}\right.$ outer $\mathrm{S}$-layer,

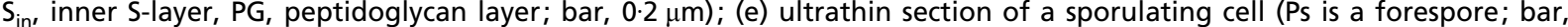
$0.5 \mu \mathrm{m}) ;(f)$ ultrathin section of a branching form (bar, $0.5 \mu \mathrm{m})$. 


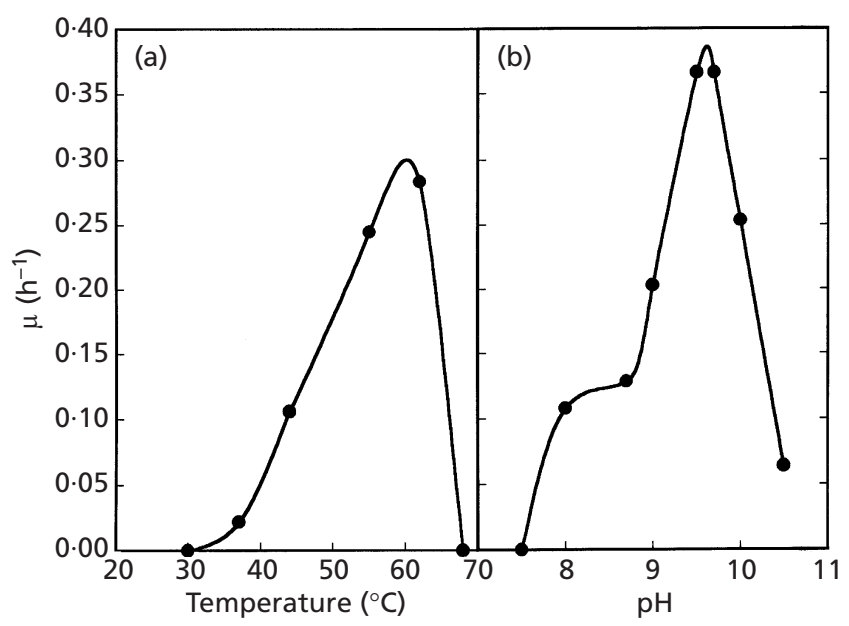

Fig. 2. Dependence of the growth of strain $\mathrm{K} 1^{\top}$ on temperature (a) and $\mathrm{pH}$ (b).

Table 1. Fatty acids of Anoxybacillus pushchinensis $\mathrm{K} 1^{\top}$

The medium contained $\left(\mathrm{g} \mathrm{l}^{-1}\right): \mathrm{KH}_{2} \mathrm{PO}_{4}, 0 \cdot 2 ; \mathrm{MgCl}_{2} \cdot 6 \mathrm{H}_{2} \mathrm{O}$, $0 \cdot 1 ; \mathrm{KCl}, 0 \cdot 2 ; \mathrm{NH}_{4} \mathrm{Cl}, 1 \cdot 0 ; \mathrm{Na}_{2} \mathrm{CO}_{3}, 2 \cdot 76 ; \mathrm{NaHCO}_{3}, 10 \cdot 0$; $\mathrm{NaCl}, 5 \cdot 0 ; \mathrm{Na}_{2} \mathrm{~S} .9 \mathrm{H}_{2} \mathrm{O}, 0.5$; yeast extract, 0.01 (Difco); and glucose, $5 \cdot 0$. The $\mathrm{pH}$ of the medium was of 9.5-9.7. The culture was grown at $55-62{ }^{\circ} \mathrm{C}$.

\begin{tabular}{|lc|}
\hline Fatty acid & $\begin{array}{c}\text { Percentage of total fatty acids in } \\
\text { Anoxybacillus pushchinensis } \mathbf{K 1}^{\mathbf{T}}\end{array}$ \\
\hline $\mathrm{C}_{12: 0}$ & $6 \cdot 9$ \\
$\mathrm{C}_{14: 0}$ & $7 \cdot 3$ \\
iso-C $_{15: 0}$ & $38 \cdot 7$ \\
anteiso-C & $2 \cdot 0$ \\
$\mathrm{C}_{15: 0}$ & $0 \cdot 9$ \\
iso-C $_{16: 0}$ & $0 \cdot 3$ \\
$\mathrm{C}_{16: 1}$ & $2 \cdot 6$ \\
$\mathrm{C}_{16: 0}$ & $14 \cdot 5$ \\
$10 \mathrm{Me}-\mathrm{C}_{16: 0}$ & $0 \cdot 9$ \\
iso-C $_{17: 0}$ & $0 \cdot 8$ \\
anteiso-C $_{17: 0}$ & $0 \cdot 1$ \\
hydroxyiso-C $_{15: 0}$ & $0 \cdot 3$ \\
$\mathrm{C}_{17: 0}$ & $0 \cdot 5$ \\
$\mathrm{C}_{18: 2}$ & $2 \cdot 2$ \\
$\mathrm{C}_{18: 1 \delta 9}$ & $4 \cdot 3$ \\
$\mathrm{C}_{18: 1 \delta 1}$ & $1 \cdot 0$ \\
$\mathrm{C}_{18: 0}$ & $10 \cdot 4$ \\
$\mathrm{C}_{20: 0}$ & $0 \cdot 6$ \\
\hline
\end{tabular}

\section{Genotypic characteristics}

The $\mathrm{G}+\mathrm{C}$ content of the DNA of strain $\mathrm{K} 1^{\mathrm{T}}$ was $42 \cdot 2 \pm 0 \cdot 2 \mathrm{~mol} \%$, a value similar to that of ' $B$. flavothermus' DSM $2641(41 \cdot 6 \pm 0 \cdot 2 \mathrm{~mol} \%$, as determined in this work). The level of DNA relatedness between these strains was $58.8 \%$. The levels of DNA relatedness of strain $\mathrm{K} 1{ }^{\mathrm{T}}$ with Clostridium stercorarium NCIMB $11754(\mathrm{G}+\mathrm{C}$ content of $40 \cdot 2 \mathrm{~mol} \%)$, Bacillus pasteurii VKM B $513(\mathrm{G}+\mathrm{C}$ content of $38.5 \mathrm{~mol} \%)$ and Thermoanaerobacter thermohydrosulfuricus DSM $567^{\mathrm{T}}(\mathrm{G}+\mathrm{C}$ content of $37 \mathrm{~mol} \%)$ were 21,20 and $4 \%$, respectively.

\section{Phylogenetic analysis}

A length of $1340 \mathrm{bp}$ of $16 \mathrm{~S}$ rDNA of strain $\mathrm{K} 1^{\mathrm{T}}$ was sequenced on both strands. The sequence was compared with the $16 \mathrm{~S}$ rDNA sequences of some representatives of the Bacillus group by using the Phylogenetic Inference Package (version 3.5) (Felsenstein, 1989).

Phylogenetic analysis revealed a clusterization with ' $B$. flavothermus' (98.89\% sequence similarity). These bacteria differed by 7-16\% from other species of the genus Bacillus and they can, therefore, be distinguished as a separate genus. Strain $\mathrm{K} 1^{\mathrm{T}}$ and ' $B$. flavothermus' form an individual branch among the other bacillus rDNA groups. Table 2 shows the position of strain $\mathrm{K} 1^{\mathrm{T}}$ in the phylogenetic cluster of related bacteria.

\section{DISCUSSION}

Table 3 summarizes data of bacteria of the genera Bacillus and Thermoanaerobacter, which are most similar in their physiology to strain $\mathrm{K} 1^{\mathrm{T}}$, despite some remarkable differences existing between them. Thus, strain $\mathrm{K} 1^{\mathrm{T}}$ differs from ' $B$. flavothermus' in its morphology, cell size, motility (no peritrichous flagellation), and $\mathrm{pH}$ range and optimum. Unlike ' $B$. flavothermus', strain $\mathrm{K} 1^{\mathrm{T}}$ cannot grow at 30 or $70{ }^{\circ} \mathrm{C}$; its growth temperature ranges from 37 to $65^{\circ} \mathrm{C}$. In addition, strain $\mathrm{K} 1^{\mathrm{T}}$ is unable to utilize peptone and yeast extract as substrates, does not hydrolyse casein, cannot grow under aerobic conditions and is catalasenegative. Cells of Thermoanaerobacter thermohydrosulfuricus are motile, have a lower DNA G $+\mathrm{C}$ content than strain $\mathrm{K} 1^{\mathrm{T}}$ cells, exhibit a remarkably different range and optimum of temperatures and $\mathrm{pH}$ for growth, and are able to utilize yeast extract. Cells of Bacillus pasteurii (Sneath, 1986) are larger in size than cells of strain $\mathrm{K} 1^{\mathrm{T}}$, exhibit different optimal and ultimate temperature and $\mathrm{pH}$ values, are tolerant to $\mathrm{NaCl}$ up to $10 \%$, can hydrolyse gelatin and casein, and, finally, grow as facultatively anaerobic bacteria. It should be emphasized that strain $\mathrm{K}^{\mathrm{T}}$ can be distinguished from all other strains chosen for comparison by the obligate dependence of its growth on the $\mathrm{CO}_{3}^{2-}$ ion and a tendency toward the formation of branched cells. The $16 \mathrm{~S}$ rDNA of strain $\mathrm{K} 1^{\mathrm{T}}$ was compared with GenBank database sequences using the FASTA program (Pearson \& Lipman, 1988). The comparison revealed the highest degree of similarity of the strain with representatives of the genus Bacillus sensu stricto and related taxa. A strictly anaerobic species of the genus Bacillus, Bacillus infernus, has already been described (Boone et al., 1995) but this species clearly belongs to a different cluster within this phyletic group. Comparisons of $16 \mathrm{~S}$ rDNA sequences indicated the significant difference $(>80 \%)$ between strain $\mathrm{K} 1^{\mathrm{T}}$ and 
Table 2. $16 \mathrm{~S}$ rDNA difference values between strain $\mathrm{K} 1^{\top}$ and related taxa

Values for Anoxybacillus pushchinensis sp. nov. and Anoxybacillus flavithermus comb. nov. DSM 2641 ${ }^{\mathrm{T}}$ (Z26932) (formerly 'Bacillus flavothermus') are shown in bold. Species are as follows (accession numbers are given in parentheses): 1, Anoxybacillus pushchinensis sp. nov.; 2, Bacillus sp. strain 13 DSM 2349 (Z26929); 3, Bacillus pallidus DSM 3670 (Z26930); 4, 'Bacillus thermoalkalophilus' DSM 6866 (Z26931); 5, Alicyclobacillus acidocaldarius DSM 446 ${ }^{\mathrm{T}}$ (X60742); 6, Bacillus pasteurii NCIB 8841 ${ }^{\mathrm{T}}$ (X60631); 7, Anoxybacillus flavithermus comb. nov. DSM 2641 ${ }^{\mathrm{T}}$ (Z26932) (formerly 'Bacillus flavothermus'); 8, Bacillus pseudofirmus DSM 8715 (X76439); 9, Bacillus cereus NCTC 11143 (55063); 10, Bacillus alcalophilus DSM 485 ${ }^{\mathrm{T}}$ (X76436); 11, Bacillus pseudalcaliphilus DSM 8725 $5^{\mathrm{T}}$ (X76449); 12, Bacillus gibsonii DSM 8722 $2^{\mathrm{T}}$ (X76446); 13, Bacillus clausii DSM 8716 ${ }^{\mathrm{T}}$ (X76440); 14, Bacillus megaterium DSM 32 ${ }^{\mathrm{T}}$ (X60629); 15, Bacillus horikoshii DSM 8719 (X76443); 16, Aneurinibacillus aneurinolyticus ATCC 12856 ${ }^{\mathrm{T}}$ (D78455); 17, Bacillus brevis NCIB 9372 ${ }^{\mathrm{T}}$ (X60612); and 18, Thermoanaerobacter thermohydrosulfuricus E100-69 (L09161).

\begin{tabular}{|c|c|c|c|c|c|c|c|c|c|c|c|c|c|c|c|c|c|}
\hline Species & 1 & 2 & 3 & 4 & 5 & 6 & 7 & 8 & 9 & 10 & 11 & 12 & 13 & 14 & 15 & 16 & 17 \\
\hline 2 & $7 \cdot 1$ & & & & & & & & & & & & & & & & \\
\hline 3 & $7 \cdot 2$ & $0 \cdot 1$ & & & & & & & & & & & & & & & \\
\hline 4 & $7 \cdot 1$ & $0 \cdot 6$ & $0 \cdot 6$ & & & & & & & & & & & & & & \\
\hline 5 & $18 \cdot 4$ & $17 \cdot 5$ & $17 \cdot 5$ & $17 \cdot 9$ & & & & & & & & & & & & & \\
\hline 6 & $10 \cdot 9$ & $10 \cdot 4$ & $10 \cdot 5$ & $10 \cdot 7$ & $18 \cdot 0$ & & & & & & & & & & & & \\
\hline 7 & $\mathbf{1} \cdot \mathbf{1}$ & $6 \cdot 1$ & $6 \cdot 3$ & $6 \cdot 6$ & $17 \cdot 1$ & $9 \cdot 5$ & & & & & & & & & & & \\
\hline 8 & $11 \cdot 7$ & $9 \cdot 4$ & $9 \cdot 3$ & $9 \cdot 6$ & $18 \cdot 3$ & $10 \cdot 3$ & $10 \cdot 4$ & & & & & & & & & & \\
\hline 9 & $10 \cdot 6$ & $9 \cdot 4$ & $9 \cdot 4$ & $9 \cdot 4$ & $20 \cdot 0$ & $10 \cdot 7$ & $9 \cdot 7$ & $7 \cdot 2$ & & & & & & & & & \\
\hline 10 & $11 \cdot 5$ & $9 \cdot 0$ & $8 \cdot 9$ & $9 \cdot 5$ & $19 \cdot 1$ & $11 \cdot 0$ & $10 \cdot 2$ & $4 \cdot 2$ & $8 \cdot 8$ & & & & & & & & \\
\hline 11 & $11 \cdot 3$ & $8 \cdot 6$ & $8 \cdot 7$ & $9 \cdot 1$ & $19 \cdot 8$ & $11 \cdot 4$ & $10 \cdot 4$ & $4 \cdot 8$ & $8 \cdot 4$ & $2 \cdot 1$ & & & & & & & \\
\hline 12 & $13 \cdot 0$ & $9 \cdot 7$ & $9 \cdot 9$ & $10 \cdot 0$ & $19 \cdot 6$ & $11 \cdot 8$ & $11 \cdot 6$ & $6 \cdot 6$ & $10 \cdot 4$ & $6 \cdot 4$ & $6 \cdot 8$ & & & & & & \\
\hline 13 & $12 \cdot 2$ & $8 \cdot 0$ & $8 \cdot 2$ & $8 \cdot 5$ & $19 \cdot 1$ & $11 \cdot 3$ & $10 \cdot 9$ & $6 \cdot 3$ & $9 \cdot 5$ & $5 \cdot 8$ & $6 \cdot 1$ & $6 \cdot 0$ & & & & & \\
\hline 14 & $10 \cdot 1$ & $9 \cdot 4$ & $9 \cdot 5$ & $9 \cdot 6$ & $19 \cdot 4$ & $9 \cdot 7$ & $9 \cdot 1$ & $7 \cdot 1$ & $5 \cdot 7$ & $9 \cdot 2$ & $8 \cdot 8$ & $10 \cdot 1$ & $9 \cdot 5$ & & & & \\
\hline 15 & $13 \cdot 0$ & $9 \cdot 7$ & $9 \cdot 9$ & $10 \cdot 0$ & $19 \cdot 6$ & $11 \cdot 8$ & $11 \cdot 6$ & $6 \cdot 6$ & $10 \cdot 3$ & $6 \cdot 4$ & $6 \cdot 8$ & $0 \cdot 0$ & $6 \cdot 0$ & $10 \cdot 1$ & & & \\
\hline 16 & $15 \cdot 4$ & $12 \cdot 5$ & $12 \cdot 5$ & $13 \cdot 1$ & $18 \cdot 5$ & $13 \cdot 5$ & $13 \cdot 9$ & $12 \cdot 0$ & $13 \cdot 1$ & $13 \cdot 8$ & $14 \cdot 5$ & $14 \cdot 6$ & $13 \cdot 2$ & $13 \cdot 6$ & $14 \cdot 6$ & & \\
\hline 17 & $14 \cdot 3$ & $11 \cdot 6$ & $11 \cdot 6$ & $12 \cdot 1$ & $18 \cdot 7$ & $12 \cdot 0$ & $13 \cdot 0$ & $11 \cdot 9$ & $12 \cdot 6$ & $11 \cdot 7$ & $11 \cdot 7$ & $12 \cdot 1$ & $11 \cdot 7$ & $12 \cdot 0$ & $12 \cdot 1$ & $10 \cdot 3$ & \\
\hline 18 & $33 \cdot 0$ & 35.9 & $35 \cdot 8$ & $35 \cdot 8$ & $35 \cdot 7$ & $38 \cdot 4$ & $34 \cdot 3$ & $34 \cdot 1$ & $35 \cdot 2$ & $34 \cdot 0$ & $34 \cdot 3$ & $35 \cdot 8$ & $33 \cdot 5$ & $36 \cdot 7$ & $35 \cdot 8$ & $35 \cdot 1$ & $34 \cdot 8$ \\
\hline
\end{tabular}

B. infernus. Due to this large difference, the latter species was not included in Table 2. 'B. flavothermus' was the closest relative of strain $\mathrm{K} 1^{\mathrm{T}}$, their $16 \mathrm{~S}$ rDNA sequences exhibiting $98.8 \%$ similarity to each other. However, the $16 \mathrm{~S}$ rDNA relatedness of strain $\mathrm{K} 1^{\mathrm{T}}$ and ' $B$. flavothermus' is inconsistent with the phenotypic features which are clearly different for these two organisms. It is known that the analysis of $16 \mathrm{~S}$ rDNA sequences may be insufficient to distinguish between species (Vandamme et al., 1996). Therefore, DNADNA hybridization was performed, which showed $58.8 \%$ similarity between the two strains. This indicates that strain $\mathrm{K} 1^{\mathrm{T}}$ and ' $B$. flavothermus' represent different species. Because 16S rDNA sequence similarity of these bacteria differed by $7-16 \%$ from those of other representatives of the genus Bacillus and its relatives, they can be distinguished as a separate taxon at the generic level (Tables 3 and 4). Based on the morphological and physiological features determined, as well as the data of genetic analyses, it is proposed that strain $\mathrm{K}^{\mathrm{T}}$ be placed in a new genus, Anoxybacillus, as a new species, Anoxybacillus pushchinensis gen. nov., sp. nov.

The aim of the present investigation was mainly the elucidation of the taxonomic structure of strain $\mathrm{K}^{\mathrm{T}}{ }^{\text {. }}$.
However, based on a comparison of physiological and chemotaxonomic data and genetic characterizations, including determination of $\mathrm{G}+\mathrm{C}$ content of DNA, DNA-DNA hybridization and 16S rDNA analysis (our data; Heinen et al., 1982; Claus \& Berkeley, 1986; Ash et al., 1991; Sharp et al., 1992; Rainey et al., 1994), this new genus should also include the species 'B. flavothermus'(strain d.y = DSM 2641), the name having not been validly published. It is, therefore, proposed that ' $B$. flavothermus' be placed also in the genus Anoxybacillus as Anoxybacillus flavithermus comb. nov.

\section{Description of Anoxybacillus gen. nov.}

Anoxybacillus (An.o.xy.ba.cil'lus. Gr. pref. an without; M.L. oxy shortened from oxygenium, oxygen; L. masc. n. bacillus small rod; N.L. masc. n. Anoxybacillus small rod living without oxygen).

Cells are rod-shaped and straight, $0.4-0.85 \times 2.5$ $3.0 \mu \mathrm{m}$, often arranged in pairs or chains, with rounded ends. Gram-positive. Endospores are round and resistant to heating and freezing. Spores are located at the end of the cell. There is not more than one spore per cell. Obligately anaerobic or facultatively anaer- 
Table 3. Comparison of Anoxybacillus pushchinensis $\mathrm{K} 1^{\top}$ with bacteria that have similar physiology and $\mathrm{G}+\mathrm{C}$ content

Species are as follows: 1, Anoxybacillus pushchinensis strain K1 $1^{\mathrm{T}}$ (this work); 2, 'Bacillus flavothermus' strain d.y. DSM 2641 (Heinen et al., 1982); 3, Thermoanaerobacter thermohydrosulfuricus DSM 567 (Klaushofer \& Parkkinen, 1965); 4, Bacillus pasteurii VKM B-513 (Sneath, 1986).

\begin{tabular}{|c|c|c|c|c|}
\hline Characteristic & 1 & 2 & 3 & 4 \\
\hline \multicolumn{5}{|l|}{ Morphology } \\
\hline Shape of cells & Rod & Rod & Rod & Rod \\
\hline Motility & - & + & + & + \\
\hline Spore formation & + & + & + & + \\
\hline Size $(\mu \mathrm{m})$ & $0.5-0.6 \times 3 \cdot 0-5 \cdot 0$ & $0 \cdot 85 \times 2 \cdot 3-7 \cdot 1$ & $0.4-0.6 \times 1.8-13.0$ & $0 \cdot 5-1 \cdot 2 \times 1 \cdot 3-4 \cdot 0$ \\
\hline DNA G $+C(\mathrm{~mol} \%)$ & $42 \cdot 2$ & $42 \cdot 3 / 61 \cdot 0^{*}$ & 37 & $38 \cdot 5-42 \cdot 0$ \\
\hline \multicolumn{5}{|l|}{ Temperature $\left({ }^{\circ} \mathrm{C}\right)$ : } \\
\hline Range & $37-66$ & $30-72$ & $42-78$ & $15-40$ \\
\hline Optimum & 62 & $60-65$ & $67-69$ & 30 \\
\hline \multicolumn{5}{|l|}{$\mathrm{pH}:$} \\
\hline Range & $8 \cdot 0-10 \cdot 5$ & $5 \cdot 5-9 \cdot 0$ & $5 \cdot 5-9 \cdot 2$ & $6 \cdot 5-9 \cdot 5$ \\
\hline Optimum & $9 \cdot 5-9 \cdot 7$ & $7 \cdot 0$ & $6 \cdot 9-7 \cdot 5$ & $9 \cdot 0$ \\
\hline Tolerance to $\mathrm{NaCl}(\%)$ & $3 \cdot 0$ & $2 \cdot 5$ & ND & 10 \\
\hline \multicolumn{5}{|l|}{ Substrate: } \\
\hline Glucose & + & - & + & + \\
\hline Sucrose & + & - & + & + \\
\hline Starch & + & - & + & ND \\
\hline Peptone & - & + & - & + \\
\hline Yeast extract & - & + & + & ND \\
\hline Lactate & - & - & - & ND \\
\hline Relation to $\mathrm{O}_{2}$ & Anaerobe & Facultative aerobe & Anaerobe & Facultative aerobe \\
\hline Catalase activity & - & + & - & ND \\
\hline $\mathrm{NO}_{3}^{-}$reduction & + & + & $+/-$ & + \\
\hline Hydrolysis of gelatin & - & - & - & + \\
\hline Hydrolysis of casein & - & + & $+/-$ & + \\
\hline
\end{tabular}

* $\mathrm{G}+\mathrm{C}$ values of $42 \cdot 3$ and $61 \cdot 0 \mathrm{~mol} \%$ from H. Hippe (DSMZ) and Heinen et al. (1982), respectively.

Table 4. Comparison of Anoxybacillus gen. nov. with genera that have similar endospore formation

Genera are as follows: 1, Anoxybacillus; 2, Amphibacillus; 3, Bacillus; 4, Clostridium; 5, Desulfotomaculum; and 6, Sporolactobacillus. All genera are rod-shaped and produce endospores.

\begin{tabular}{|c|c|c|c|c|c|c|}
\hline Characteristic & 1 & 2 & 3 & 4 & 5 & 6 \\
\hline Motility & $-/+$ & + & + & + & + & + \\
\hline Gram reaction & + & + & + & $+/-($ rare $)$ & $+(11-89 \%$ strains $)$ & + \\
\hline Relation to $\mathrm{O}_{2}$ & $\begin{array}{c}\text { Anaerobe/ } \\
\text { facultative } \\
\text { aerobe }\end{array}$ & $\begin{array}{l}\text { Facultative } \\
\text { aerobe }\end{array}$ & $\begin{array}{c}\text { Anaerobe/ } \\
\text { facultative } \\
\text { aerobe }\end{array}$ & $\begin{array}{c}\text { Anaerobe } \\
\text { (aerotolerant) }\end{array}$ & $\begin{array}{l}\text { Obligate } \\
\text { anaerobe }\end{array}$ & $\begin{array}{c}\text { Anaerobe/ } \\
\text { facultative } \\
\text { aerobe }\end{array}$ \\
\hline $\mathrm{SO}_{4}^{2-}$ reduction & - & - & - & - & + & - \\
\hline Catalase activity & $+/-$ & - & + & - & - & - \\
\hline Oxidase activity & $+/-$ & - & $+/-$ & - & - & - \\
\hline $\mathrm{NO}_{3}^{-}$reduction to $\mathrm{NO}_{2}^{-}$ & + & - & $+/-$ & $+/-$ & - & - \\
\hline $\mathrm{NaCl}$ requirement $(3-12 \%)$ & - & - & $+/-$ & - & - & - \\
\hline $\begin{array}{l}\text { Lactate as sole product of } \\
\text { carbohydrate fermentation }\end{array}$ & - & - & $+1-$ & - & - & + \\
\hline
\end{tabular}


obic; catalase variable. Alkaliphilic or alkalitolerant, thermophilic. Chemo-organotrophic, with a fermentative metabolism. DNA $\mathrm{G}+\mathrm{C}$ content is around $42 \mathrm{~mol} \%$. Includes two species: Anoxybacillus pushchinensis and Anoxybacillus flavithermus. The type species of the genus is Anoxybacillus pushchinensis.

\section{Description of Anoxybacillus pushchinensis sp. nov.}

Anoxybacillus pushchinensis (push.chi.nen'sis. N.L. masc. adj. pushchinensis pertaining to Pushchino, a research centre near Moscow, Russia, where the organism was isolated).

Straight rods, $0.4-0.5 \times 2.5-3.0 \mu \mathrm{m}$ in size, single, in pairs, sometimes in chains, Gram-positive, non-motile. Y-shaped cells occur. Forms round endospores. Anaerobic, chemoheterotrophic, alkaliphilic, moderately thermophilic bacterium. Grows at $37-65^{\circ} \mathrm{C}$, with an optimum at $62{ }^{\circ} \mathrm{C}$. Obligate alkaliphile that cannot grow at $\mathrm{pH} 7 \cdot 0$; grows in a $\mathrm{pH}$ range of $8 \cdot 0-10.5$ with an optimum at 9.5-9.7. $\mathrm{CO}_{3}^{2-}$ is obligately required. Optimal growth at $1 \% \mathrm{NaCl}$, tolerant to $3 \% \mathrm{NaCl}$. Growth substrates are D-glucose, sucrose, D-fructose, D-trehalose and starch. The major fermentation products are hydrogen and acetic acid. Nitrate is reduced to nitrite. Sulfate, sulfite, thiosulfate and sulfur are not reduced. Yeast extract stimulates growth. Vitamins are required. Catalase-negative. Gelatin and casein are not hydrolysed. DNA G $+\mathrm{C}$ content is $42.2 \pm 0.2 \mathrm{~mol} \%$. Source: cow and pig manure with neutral $\mathrm{pH}$. Type strain: $\mathrm{K} 1^{\mathrm{T}}$. This strain has been deposited at the Deutsche Sammlung von Mikroorganismen und Zellkulturen (as DSM 12423 ${ }^{\mathrm{T}}$ ), at the American Type Culture Collection (as ATCC $700785^{\mathrm{T}}$ ) and at the All-Russia Collection of Microorganisms (as VKM B-2193 ${ }^{\mathrm{T}}$ ).

\section{Description of Anoxybacillus flavithermus comb. nov.}

Anoxybacillus flavithermus (fla.vi.ther'mus. L. adj. flavus yellow; Gr. adj. thermos warm; N.L. adj. flavithermus to indicate a yellow thermophilic organism).

Data are from Heinen et al. (1982), Claus \& Berkeley (1986), Sharp et al. (1992), Rainey et al. (1994) and this study. Rods, $0.85 \times 2.3-7 \cdot 1 \mu \mathrm{m}$. Motile. Gram-positive. Spores terminal. Colonies round, smooth, yellow. Facultatively anaerobic. Catalase-positive. Oxidasepositive. Starch but not gelatin hydrolysed. Grows in peptone-yeast extract media. Glucose, mannose, maltose, sucrose, arabinose, rhamnose and sorbitol utilized. Positive for acetoin, arginine dihydrolase, lysine decarboxylase, tryptophan deaminase and $\beta$ galactosidase. Nitrate reduced to nitrite. Urease, ornithine decarboxylase, indole and $\mathrm{H}_{2} \mathrm{~S}$ not produced. Growth in $2.5 \% \mathrm{NaCl}$ broth, but not in $3 \% \mathrm{NaCl}$. Optimum $\mathrm{pH}$ for growth of 6-9. No growth at $\mathrm{pH} 5 \cdot 0$. Temperature range for growth $30-72{ }^{\circ} \mathrm{C}$; optimum growth at $60{ }^{\circ} \mathrm{C}$ (aerobic) and $65^{\circ} \mathrm{C}$ (anaerobic). Source: hot spring, New Zealand. DNA G + C content of $41.6 \mathrm{~mol} \%$ (by HPLC method). Type strain: d.y. ${ }^{\mathrm{T}}$ $\left(=\right.$ DSM $\left.2641^{\mathrm{T}}\right)$.

\section{ACKNOWLEDGEMENTS}

We are grateful to Dr A. V. Lebedinskyi and Dr A. L. Mulukin for editing the English version of this article. This work was in part supported by the RFFI grant 99-04-49144.

\section{REFERENCES}

Ash, C., Farrow, A. E., Wallbanks, S. \& Collins, M. D. (1991). Phylogenetic heterogeneity of the genus Bacillus revealed by comparative analysis of small-subunit-ribosomal RNA sequences. Lett Appl Microbiol 13, 202-206.

Boone, D. R., Liu, Y., Zhao, Z.-J., Balkwill, D. L., Drake, G. R., Stevens, T. O. \& Aldrich, H. C. (1995). Bacillus infernus sp. nov., an $\mathrm{Fe}(\mathrm{III})$ - and $\mathrm{Mn}(\mathrm{IV})$-reducing anaerobe from the deep terrestrial subsurface. Int J Syst Bacteriol 45, 441-448.

Cashion, P., Holder-Franklin, M. A., McCully, J. \& Franklin, M. (1977). A rapid method for the base ratio determination of bacterial DNA. Anal Biochem 81, 461-466.

Claus, D. \& Berkeley, R. C. W. (1986). Genus Bacillus. Cohn 1872 , $174^{\mathrm{AL}}$. In Bergey's Manual of Systematic Bacteriology, vol. 2, pp. 1105-1139. Edited by P. H. A. Sneath, N. S. Mair, M. E. Sharpe \& J. G. Holt. Baltimore: Williams \& Wilkins.

De Ley, J., Cattoir, H. \& Reynaerts, A. (1970). The quantitative measurement of DNA hybridization from renaturation rates. Eur J Biochem 12, 133-142.

Downie, A. W. \& Cruickshank, J. (1928). The resistance of Streptococcus faecalis to acid and alkaline media. $\mathrm{Br} J \mathrm{Exp}$ Pathol 9, 171-173.

Edwards, U., Rogall, T., Blöker, H., Ende, M. D. \& Böttger, E. C. (1989). Isolation and direct complete nucleotide determination of entire genes. Characterization of gene coding for $16 \mathrm{~S}$ ribosomal RNA. Nucleic Acids Res 17, 7843-7853.

Engle, M., Li, Y., Woese, C. \& Wiegel, J. (1995). Isolation and characterization of a novel alkali-tolerant thermophile, Anaerobranca horikoshii gen. nov., sp. nov. Int J Syst Bacteriol 45, 454-461.

Escara, J. F. \& Hutton, J. R. (1980). Thermal stability and renaturation of DNA in dimethyl sulphoxide solutions: acceleration of the renaturation rate. Biopolymers 19, 1315-1327.

Felsenstein, J. (1989). PHYLIP: phylogeny inference package. (version 3.2). Cladistics 5, 164-166.

Gerhardt, P., Murray, R. G. E., Wood, W. A. \& Krieg, N. R. (editors) (1984). Manual of Methods for General Bacteriology. Washington, DC: American Society for Microbiology.

Grant, W. D. \& Tindall, B. J. (1986). The alkaline saline environment. In Microbes in Extreme Environments, pp. 25-54. Edited by R. A. Herbert \& G. A. Codd. London: Academic Press.

Heinen, W., Lauwers, A. M. \& Mulders, J. W. M. (1982). Bacillus flavothermus, a newly isolated facultative thermophile. Antonie Leeuwenhoek J Microbiol Serol 48, 265-272.

Horikoshi, K. \& Akiba, T. (1982). Alkalophilic Microorganisms : a New Microbial World. New York: Springer.

Huß, V. A. R., Festl, H. \& Schleifer, K. H. (1983). Studies on the spectrophotometric determination of DNA hybridization from renaturation rates. Syst Appl Microbiol 4, 184-192.

Jahnke, K.-D. (1992). BASIC computer program for evaluation of spectroscopic DNA renaturation data from Gilford System 
2600 spectrophotometer on a PC/XT/AT type personal computer. J Microbiol Methods 15, 61-73.

Klaushofer, H. \& Parkkinen, E. (1965). Zur Frage der Bedeutung aerober und anaerober thermophiler sporenbildner als Infektionsursache in Rubenzukerfabriken. I. Clostridium thermohydrosulfuricum eine neue Art eines saccharoseabauenden, thermophilen, schwefelwasserstoffbildenden Clostridiums. Z Zuckerind Boehm 15, 445-449.

Krulwich, T. A. \& Guffanti, A. (1989). Alkalophilic bacteria. Annu Rev Microbiol 43, 435-463.

Li, Y., Mandelco, L. \& Wiegel, J. (1993). Isolation and characterization of a moderately thermophilic anaerobic alkaliphile, Clostridium paradoxum sp. nov. Int J Syst Bacteriol 43, 450-460.

Li, Y., Engle, M., Weiss, N., Mandelco, L. \& Wiegel, J. (1994). Clostridium alcaliphilum sp. nov., an anaerobic and thermotolerant facultative alkaliphile. Int J Syst Bacteriol 44, 111-118. Marmur, G. (1961). A procedure for the isolation of DNA from microorganisms. J Mol Biol 3, 208-218.

Mesbah, M., Premachandran, U. \& Whitman, B. (1989). Precise measurement of the $\mathrm{G}+\mathrm{C}$ content of deoxyribonucleic acid by high-performance liquid chromatography. Int J Syst Bacteriol 39, 159-167.

Pearson, W. R. \& Lipman, D. J. (1988). Improved tools for biological sequence comparison. Proc Natl Acad Sci USA 85, 2444-2448.

Rainey, F. A., Fritze, D. \& Stackebrandt, E. (1994). The phylogenetic diversity of thermophilic members of the genus Bacillus as revealed by $16 \mathrm{~S}$ rDNA analysis. FEMS Microbiol Lett 115, 205-212.
Reynolds, E. S. (1963). The use of lead citrate at high $\mathrm{pH}$ as an electron-opaque strain in electron microscopy. J Cell Biol 17, 208-212.

Sharp, R. J., Riley, P. W. \& White, D. (1992). Heterotrophic thermophilic bacilli. In Thermophilic Bacteria, pp. 19-50. Edited by J. K. Kristjansson. Boca Raton, FL: CRC Press.

Sneath, P. H. A. (1986). Endospore-forming Gram-positive rods and cocci. In Bergey's Manual of Systematic Bacteriology, vol. 2, pp. 1104-1138. Edited by P. H. A. Sneath, N. S. Mair, M. E. Sharpe \& J. G. Holt. Baltimore: Williams \& Wilkins.

Tamaoka, J. \& Komagata, K. (1984). Determination of DNA base composition by reversed-phase high-performance liquid chromatography. FEMS Microbiol Lett 25, 125-128.

Tiedje, J. M. (1982). Denitrification. In Methods in Soil Analysis, Part 2. Chemical and Microbiological Properties. Agronomy Monograph N9, pp. 1011-1026. Edited by A. L. Page. Madison, WI: American Society for Agronomy and Soil

Vandamme, P., Pot, B., Gillis, M., De Vos, P., Kersters, K. \& Swings, J. (1996). Polyphasic taxonomy, a consensus approach to bacterial systematics. Microbiol Rev 60, 407-438.

Wolin, E. A., Wolin, M. G. \& Wolfe, R. S. (1963). Formation of methane by bacterial extracts. J Biol Chem 238, 2882-2886.

Zavarzin, G. A. (1993). Epicontinental alkaline water bodies as relict biotopes for development of terrestrial biota. Mikrobiologiya 62, 789-800 (in Russian).

Zhilina, T. N., Zavarzin, G. A., Rainey, F. A., Pikuta, E. V., Osipov, G. A. \& Kostrikina, N. A. (1997). Desulfonatronovibrio hydrogenovorans gen. nov., sp. nov., an alkaliphilic sulfate-reducing bacterium. Int J Syst Bacteriol 47, 144-149. 